\title{
Structures of Piety in Elizabeth Richardson's Legacie
}

\author{
Michelle M. Dowd
}

In 1645, Elizabeth Richardson published A Ladies Legacie to her Daughters, a book of prayers intended as both an advice book and a devotional aid for her children. As a book of practical and spiritual guidance, the Legacie has a place within a subgenre of women's life writings in early modern England that has come , to be known as mothers' legacies. These books were ostensibly directed at a very small audience: they were usually dedicated to the writer's children and designed to offer maternal advice that could outlive the author herself. However, though texts in this tradition had been written and circulated in England from the 800s, the seventeenth century witnessed a striking surge in the publication and dissemination of these books, particularly by Protestant women. As Valerie Wayne has demonstrated, the influence of humanist positions about motherhood, advocated most forcefully by Erasmus, combined with widespread sympathy for the plight of Elizabeth Stuart, exiled daughter to James I and a popular symbol for both Protestantism and maternal nurturance, may have provided both the "ideological justification" and the "politico-religious occasion" for these mothers' advice books.' These texts thus performed a dual function: they served as personal collections of practical and spiritual guidance intended for individual family members, and they also participated more broadly in the process of advocating Protestant ethics and spirituality during a tumultuous period of political and religious upheaval.

The dual function of these books might help to account for the widespread popularity that they enjoyed throughout the early modern period. The most wellknown text in this genre, Dorothy Leigh's The Mothers Blessing (1616), was dedicated to Elizabeth Stuart, and it was a seventeenth-century bestseller, running to 23 editions between 1616 and 1674. Similarly, Elizabeth Jocelin's The Mothers Legacie, To her unborne Childe (1624) went through seven editions between 1624 and $1640 .^{2}$ And yet, the popularity of these texts does not imply that their authors triumphed unproblematically over the stigmas associated with women's writing during the period. Authors of mothers' legacies often claimed their own impending 
death as the impetus for their writing, thus offering an urgent justification for the publication of their texts. As much of the criticism on legacy books has demonstrated, the genre of the mother's legacy gave women like Leigh and Jocelin authorial strategies that enabled them to publish but demanded in turn their rhetorical (and sometimes literal) self-effacement. For these women, the publication of the self often implied its erasure, either through the rhetorical transference of agency from mother to child or through the physical loss of agency at death. ${ }^{3}$

What is less often discussed, however, are the ways in which the formal structure of mothers' legacy books affected the type of written guidance these women could leave for the benefit of their surviving children and the particular role these texts could play in Protestant print culture. Since mothers' legacies were not well defined in terms of generic categorization or structural design, these texts often make creative use of a wide range of literary forms and models. This generic fluidity and potential for innovation within the legacy genre, I argue, produced unique opportunities for religious expression and self-authorization that helped to articulate the significance of maternal authority to both individual families and to Protestant communities more generally. Generic hybridity in this context becomes a politically useful and spiritually efficacious literary tool.

Given my interest in the creativity and generic flexibility of the mothers' legacy books, my focus on Elizabeth Richardson might seem counterintuitive. Born to a large and well-connected gentry family in Leicestershire, Richardson was a devout Protestant who adhered to Anglican orthodoxies. ${ }^{4}$ Her legacy book reflects her doctrinal allegiances in its contents. The 1645 edition, which is my primary focus here, begins with an epistle and preface dedicated to her four daughters, Elizabeth, Frances, Anne, and Katherine. The rest of the text is divided into three books: the first consists of scriptural meditations and prayers; Book II is almost exclusively comprised of prayers, including ones to be read on each day of the week; and the third and final book presents additional prayers, many of which are more personal in nature, "written out of crises of sorrow or sickness in her widowhood and old age." What immediately strikes a modern reader of the Legacie-particularly if it is compared to other legacy books from the period, such as those by Leigh and Jocelin-is its proclivity for set prayers. With the exception of the epistle and preface, the Legacie consists not of narrative advice or conduct-book style aphorisms, but entirely of specific prayers to be read, recited, and memorized for individual occasions. As such, Richardson's book seems to represent the antithesis of creativity or formal flexibility; it is perhaps for this reason that the Legacie has been discussed far less in the critical literature than have other mothers' advice books.

But I suggest that Richardson's book is more complex than it might first appear to be and that examining it more carefully can help us to think in new ways about the subgenre of mothers' legacy books as a whole. Richardson is undoubtedly unique within this tradition, and the structure of her set prayers can tell us a great deal about the kind of intervention she hoped to make in her family's spiritual life and in the lives of other devout Protestants. But the Legacie, despite its apparent lack of extensive personal narrative, is also in many ways an ideal case study for considering the formal flexibility of the mothers' legacies and the link between generic hybridity, self-expression, and religio-political discourse. This essay, then, has two goals: 1) to explore the historical and textual idiosyncrasies of Richardson's book that facilitate its participation in mid-seventeenth-century Protestant print culture and that enable the construction of a maternal self, and 2) to suggest that attending to formal hybridity-one of the key structural features of the Legacie-can offer a new critical method for studying the mothers' advice manuals as a genre.

Though the Legacie was clearly an important document for Richardson, her family, and their spiritual lives, it lacked the commercial popularity of many mothers' legacy books: the 1645 edition was printed in two issues, but no subsequent editions were ever produced. However, a rich textual history lies behind the 1645 edition, linking it to other early modern literary traditions and patterns of circulation. Though the Legacie was not published until 1645, Richardson began writing advice, prayers, and meditations much earlier in the century. Extant manuscripts of Richardson's work dated 1606 and 1626 demonstrate her "revising sensibility" as well as her active participation in seventeenth-century English manuscript culture. ${ }^{6}$ Indeed, Book I of the Legacie consists largely of the same material found in the 1626 manuscript (MS ASH 3501) dedicated to her daughter Elizabeth. ${ }^{7}$ Manuscript book production and circulation, as Margaret Ezell and others have demonstrated, enabled women like Richardson to establish personal networks through textual exchange and to develop intellectual and spiritual interests that could be passed on as legacies to their children. ${ }^{8}$ The 1645 edition of the Legacie in many ways continues to build upon the personal and religious networks first developed in the earlier manuscripts, providing another venue for Richardson to leave a "motherly remembrance" to her daughters consisting of "prayers faithfully offered up unto his Majesty," that is, to God (A3r, A1v). ${ }^{9}$ The textual history of Richardson's Legacie thus locates it within at least two literary traditions associated with women's writing in early modern England: women's manuscript publication of prayers and meditations and the mothers' advice writing tradition that set a precedent for the 1645 publication of the Legacie.

But the printed edition of the Legacie borrows from other early modern textual traditions that are somewhat less obvious-and less frequently discussed - than either patterns of manuscript exchange or the developing genre of the legacy book. The Legacie's explicit focus on pious devotion, for instance, closely aligns it with early modern prayer books. Yet even within the generic subset of the prayer book, Richardson had access to an assortment of textual models that represented a range of religious orthodoxies. Both Richardson's father-in-law, John Ashburnham, and 
her primary patron, the Duchess of Buckingham, for example, were Roman Catholics. In 1625, Richardson and her children took refuge at the Duke of Buckingham's Chelsea house to escape the plague, and it was there that Richardson began composing the prayers that would eventually be printed in the Legacie. ${ }^{10}$ Early in her text, Richardson credits the Duchess of Buckingham with providing a space for the Legacie to originate: "This Booke was written at Chelsey in the yeare 1625 by E.A. at the Duke of Buckinghams house, a part whereof was lent me by the good Dutches, my most honoured Lady, when the great sicknesse was in London" (A2r). Both through her husband's family and through her close association with "the good Dutches"-a personal connection directly linked to the writing and publication of the Legacie--Richardson may have become familiar with the modes of prayer associated with Catholic piety.

Though Richardson herself was not a Catholic, aspects of the Legacie demonstrate an "attraction to the set rituals and rhythms of devotion" that typified Roman Catholic Books of Hours." Like the Legacie, Books of Hours were structured as a sequence of prayers to be recited at specific hours throughout the day. And these devotional texts were enormously popular in medieval and early modern England: "[f]rom the mid-thirteenth to the mid-sixteenth century, more Books of Hours were commissioned and produced, bought and sold, bequeathed and inherited, printed and reprinted than any other text, including the Bible."12 Their primary audience was the female laity; women played an essential role in the patronage of these books, brides frequently received them as wedding gifts, and women exchanged them among family members and friends. ${ }^{13}$ It is quite possible that Richardson may have read or glanced at Books of Hours owned by either the Ashburnhams or the Buckinghams, becoming familiar with their overall structure and design and revisiting that form when she composed her Legacie. During the sixteenth century, as Kathleen Ashley has recently demonstrated, Books of Hours began to be used for family record keeping in both France and England. This use of Books of Hours as "tangible symbols of the family lineage" might have made this genre particularly appealing to Richardson as she set out to leave a "motherly remembrance" of advice and prayer to her children. ${ }^{14}$

Richardson herself, however, was very much a Protestant. As an Anglican with leanings toward Laudianism, Richardson would have looked directly to the Bible and to the Book of Common Prayer for models of daily piety and routine devotion. Though she may use the language and structure of Catholic Books of Hours to organize the content and form of her Legacie, Richardson turns most consistently to the specific refrains of the Bible and the Protestant Prayer Book to shape her personal narrative of self, family, and piety. The text of the Legacie thus borrows most evidently and most profoundly from the generic and spiritual templates offered by these two cornerstones of Protestant spiritual ideology.

Given that the "matter" of her text is "but devotions or prayers," Richardson's frequent citation of biblical passages is hardly surprising (A2r). The printed margins of the Legacie are taken up by scriptural references that link her text directly to corresponding passages in the Geneva Bible, the Bible most commonly used for personal meditation and devotional study. Richardson seems to have been particularly attracted to several biblical passages (such as Matthew 7:7, John 14:13, and Psalm 8:4-5), which she returns to frequently throughout the Legacie to structure her personal prayers. In Book III of her text, her "Prayer to God, the Lord of all grace and mercie" that begins "O most bountifull Lord God, which giveth to all men liberally, and reproacheth none, if we aske in faith and waver not" borrows from all three of these passages.

Richardson's use of the Bible is often citational, but it is also at times creative and even commercially savvy. This becomes particularly clear near the end of the Legacie, where Richardson includes a hymn under the heading, "My owne Prayer in Meeter, or to be sung as a Hymne" (M1r). As Sylvia Brown has noted, this hymn is metrically structured by alternating "tetrameter and trimester lines in a four-line stanza: the dominant metrical pattern ... of the immensely popular versification of the Psalms by Thomas Sternhold and John Hopkins."15 For this prayer, Richardson borrows indirectly from the Bible, combining her own devotional text with the metrics popularized by Sternhold and Hopkins; the Psalms provide the biblical context for her "Prayer in Meeter," but Richardson adapts that text for her own readers. Her choice of meter is particularly interesting, given that the Sternhold and Hopkins psalter was the most popular volume of metrical psalms in England between 1549 and 1700 and that the tradition of sung metrical psalms was a well-established method of spreading Protestant doctrine and building religious alliances during this period. Appealing to Puritans and Laudians alike, the Sternhold and Hopkins psalter was remarkable for its widespread popularity and its entrenched status within Protestant communities. ${ }^{16}$ By creating a new hymn within this extremely popular verse tradition, Richardson displays a keen awareness of a Protestant audience beyond her immediate family, and she ensures that her hymn will be circulated within a Protestant print culture that was enormously successful at bringing spiritual texts, like the Psalms, to a wide audience. ${ }^{17}$

Indeed, Richardson's possible personal interest in providing a Protestant devotional text to a public readership may help us account for her decision to publish the Legacie when she did. Richardson had been writing and circulating her prayers in manuscript for decades, so one might wonder why she decided to publish a new and revised version of the Legacie in 1645. As Brown notes:

That year would not have been a hopeful one for those loyal to the monarchy or the old religion. The war turned decisively against the Royalists with the Battle of Naseby in July, but perhaps more important for Richardson was the fate of The Book of Common Prayer: in 1645 it was banned and replaced by the Presbyterian Directory for Public Workshop. So, not only may Richardson have felt that prayers were especially needed in these discouraging times, she may also have been seeking, through her own prayers, to rehabilitate some of the old reassuring phrases and rhythms of common prayer. ${ }^{18}$ 
The timing of the Legacie's publication, that is, suggests that Richardson might have been eager to offer Protestant readers beyond her immediate family a published substitute for the absent "phrases and rhythms" of the Book of Common Prayer. Political and religious exigency created a space for a new text that was deeply and necessarily sutured to a past history of Protestant textual forms.

Even more suggestive than the date of the published Legacie is its publisher The title page to Richardson's volume includes the imprint: "Printed by Tho. Harper, and are to be sold at his house in Little Britaine, 1645." Harper was a printer by trade, but he also seems to have occasionally served as a bookseller and publisher. ${ }^{19}$ What little we know about Harper and his role in the book trade suggests that he may have developed a specialty in Royalist and Laudian books. In his entry for Harper in the Dictionary of Booksellers and Printers: 1641-1667, H.R. Plomer notes: "[d]uring the early years of the Rebellion he was more than once in trouble for printing pamphlets against the Parliament."20 Other books that Harper published suggest that he was particularly keen to publish defenses of the monarchy and the "true Protestant religion," most notably Thomas Heywood's A Funeral Elegie, Upon the Much Lamented Death of the Trespuissant and unmatchable King, King James, King of Great Brittaine, France and Ireland, Defender of the Faith (1625) and An Apologie and Vindication (From all false and malignant Aspersions) For His Excellencie, the right Honourable, and most Noble Robert D'Evreux, Earle of Essex, and Ewe, Viscount Hereford, Baron of Chartley, Lord Bourchier and Lovain, Inheritour of all His thrice Noble Fathers Honours and Vertues: Now Lord Generall of all the Forces in Arms in England and Wales, for the present High and Honourable Court of Parliament, in defence of the true Protestant Religion, Laws and Liberties of the Subject (1644). Harper's association with the publisher Nicholas Vavasour, for whom he printed an overtly Royalist text, Thomas de Grey's The Compleat Horseman and Expert Ferrier (1639), further suggests that Harper may have specialized in published defenses of ceremonialism and the Book of Common Prayer, since, as Zachary Lesser has recently argued, Vavasour demonstrated a professional interest in exactly these types of publications. ${ }^{21}$ The publication history of Richardson's Legacie, in other words, situates her text within a Protestant political discourse that is decidedly Royalist and Laudian in nature. As such, Richardson's legacy book offers an intentional and highly politicized substitution for the recently banned Book of Common Prayer, insisting that the "phrases and rhythms" of Protestant ceremonialism continue to find a public audience during the civil wars.

The Book of Common Prayer, produced and published under the reign of Edward VI, was intended both as a thorough reform of traditional liturgy and as a means of prescribing uniformity in Protestant worship and ceremonial practice throughout England. John E. Booty notes:

The Book of Common Prayer was a set liturgy with prayers whose language was not to vary. The book was to be used day by day, week by week, year by year, until the words and phrases, the sounds and music, sank into the deep recesses of the mind and there effected the reformation of the individual in mind and will ${ }^{22}$

As such, the Protestant Prayer Book stood in direct contrast to Puritan critiques of ceremonialism and set prayer, exemplified by the Puritan Prayer Book of the 1580 s, which "presumed that the most able ministers would pray as inspired in their own words. The prayers set down were examples, or directions, to be used if necessary." 23 The unvarying language of the Book of Common Prayer, on the other hand, insisted on a reiterative, communal structure to spirituality that bound together worshippers across the country. The preface to the 1559 Prayer Book specifically addresses the need for uniformity in Protestant liturgy, informing readers: "And where heretofore there hath been a great diversity in saying and singing in churches within this realm, some following Salisbury use, some Hereford use, some the use of Bangor, some of York, and some of Lincoln, now from henceforth all the whole realm shall have but one use." ${ }^{24}$ The Prayer Book thus attempted to consolidate Protestant worship in England by offering those who read it and listened to it a common language of set prayer that remained constant despite the idiosyncrasies of geography, parish, or minister. ${ }^{25}$

Richardson's Legacie follows the model of set prayer and the desire for conformity in worship that distinguished the banned Book of Common Prayer. Richardson often borrows directly from specific passages and orders of worship in the Prayer Book. For example, the "confession of sins" in Book I of the Legacie recalls the Absolution given by the minister in the Prayer Book's "Order for Morning Prayer." 26 The phrasing of the Prayer Book, "Almighty God, the Father of our Lord Jesus Christ, which desireth not the death of a sinner, but rather that he may turn from his wickedness and live" (51), becomes in Richardson's text: "for thou art the most gracious Lord, full of mercy and great compassion, and of long suffering, that desires not the death of a sinner, but that he should repent and live" (A7v). Later in Book I, a "Prayer for Tuesday morning" asks God to "cleanse and reforme the thoughts of my wicked corrupt heart, by the inspiration of thy most holy Spirit," a phrase that echoes the collect that begins the Prayer Book's "Order for the Administration of the Lord's Supper," where the minister asks God to "cleanse the thoughts of our hearts by the inspiration of thy Holy Sprit" (248). ${ }^{27}$ These types of borrowings and reformulations appear frequently throughout the Legacie, infusing Richardson's prayers with the deeply felt structures of Protestant piety and common worship. Protestant readers-particularly Anglican ones-who studied Richardson's legacy book may have felt palpably if paradoxically comforted, as they found the phrases in front of them gradually recalling the temporally inaccessible, yet strongly remembered language of the Prayer Book.

At a more subtle textual level, Richardson's legacy book shares some of the dominant stylistic characteristics of the Book of Common Prayer. The most notable of these is the prevalence of doubling. Booty explains the significance of this stylistic device in the Prayer Book: 
Doubling, which is so prevalent in the book, is often glossatory, as in the second exhortation of the Holy Communion where the two words ("love and charitie") with the same meaning explain one another. The same is true of "serche and examine," and "confesse and open his sinne." Doubling is usually emphatic. Where one word might slip too easily by, two are better suited to make the desired impact. ${ }^{28}$

Strikingly, Richardson consistently structures her prose in the Legacie according to a similar pattern of glossatory and emphatic doublings. In one prayer alone, she addresses God as a "preserver and disposer" whom we must serve with "due feare and reverence" so that we will not wallow in "weaknesse and disability" but instead learn to teach God's word in "faith and verity" (A8v-B1r). Another prayer asks that the worshipper be allowed to "please and obey thee in all things, with reverence and feare" (B3r). Where Richardson's direct borrowings of phrases from the Prayer Book serve as an overt reminder to her readers of the formal structures of Protestant worship, this ingrained stylistic pattern of doubling remakes and reimagines the underlying rhythms of that worship, the less obvious yet equally powerful structures of Protestant piety.

The general format of the Legacie - set prayers to be said on set days-further emphasizes the systematic coherence of worship envisioned by the Prayer Book As Alison Chapman has argued, the calendar devised by Archbishop Thomas Cranmer that serves as a preface to the Book of Common Prayer aids the reformers' agenda to create uniformity in Protestant worship by "laying out a common order of collective reading" and creating a "system of nationally common order of collective reading" and creating a "system of nationally Richardson dictates the precise words to be read and studied on specific days of the week and at specific times of the day. By thus controlling the shape and content of the devotions she leaves to future readers, she is able to exert a powerful authority over them not unlike Cranmer's pervasive influence over readers of the Prayer Book. The set prayers of the Legacie, like the set liturgy of the Book of Common Prayer, discourage extemporaneous worship and instead create a Protestant community sustained by conformity. ${ }^{30}$

The overt structure of Richardson's text and her citations and stylistic borrowings from the Book of Common Prayer thus seem designed largely to provide a rigid structure of devotion that can substitute for the banned Prayer Book. But this is only part of the story. While maintaining this formal template, Richardson manages to infuse it with personal and familial significance and unique opportunities for individualization. Though the Prayer Book did make room for personal interpretations of the Bible, it was not primarily intended for private use or for personalized meditations. ${ }^{31}$ Richardson's Legacie, on the other hand, was explicitly designed to be used privately, for the personal devotions of her daughters or other individuals who might purchase it. The Legacie was printed in octavo, making it easily portable and ideal for personal use. ${ }^{32}$ In the opening epistle to her daughters, Richardson urges them "often to peruse, ponder, practice, and make use of this Booke according to my intention, though of it self unworthy," suggesting both the necessity of spiritual routine-the repetitive acts of perusing and practicing-and the importance of developing that routine through an individualized process of meditation, a process that involves pondering the text and making use of it in order to achieve Richardson's "intention": to live a life of "vertue and piety" (A1v, A1r). Though the circumstances of its publication ground the Legacie in a larger political and religious discourse, this text also exhibits a sustained interest in the adaptability of Protestant piety to personal devotion.

Though set down according to a precise order and wording, Richardson's prayers allow for a great deal of spiritual experimentation and flexibility-a flexibility that is hinted at in her subtle, yet notable departures from the other generic models to which she is indebted. However much Richardson's text echoes the language and structures of the Book of Common Prayer, she still chose to write and publish her own prayers, offering her readers a new, set liturgy for reflection. In Book II of the Legacie, Richardson includes two prayers designated as "A Prayer to be said at the Church, as soone as we are come into our seat" and "A Prayer after the Sermon is ended, before we go out of the Church" (D6v, D7v). The use of the pronoun "we" rhetorically imagines a community of believers who share a common prayer. And yet, Richardson's text offers worshippers prayers that cannot be found even in the banned Prayer Book; meant to be said during Church services, these prayers from the Legacie are nonetheless extraneous to the liturgy recorded in the Book of Common Prayer. Intermingled with standard practices of Protestant worship, these extra-liturgical prayers tantalizingly suggest a community just on the margins of those practices. The Legacie creates a space for private prayers that can settle in between and fill the momentary gaps in Protestant liturgy. It also provides text for prayers to be said privately, when the reader is "from Church" and removed from the usual scope of the Prayer Book (C2r). ${ }^{33}$ Richardson's prayers, that is, exceed and supplement the spiritual possibilities of the Book of Common Prayer, enabling a greater degree of individualization and privatization.

Richardson also encourages readers to adapt and revise the specific, set language and circumstances of individual prayers. Book III of the Legacie includes a prayer with a remarkably specific headnote: "A sorrowfull widowes prayer and petition unto the gracious protector and defender of widowes, and father of the fatherlesse, which I composed shortly after the death of my dear husband: And this may also serve any other upon the like occasion" (I3r). In this prayer, Richardson mourns and commemorates the death of her second husband, Sir Thomas Richardson, in 1635. She writes:

Almighty God ... having in thy mercifull goodnesse made me see with comfort all my children, who were left destitute, now by thy provident provision and blessing, well settled for this life.... And now, O Lord, since it hath been thy will and pleasure, to take away, and call to thy selfe my deare husband out of this transitory life before me, and to 
bereave me of him who was my chiefe comfort in this world: I humbly beseech thee, vouchsafe to take me into thy care, and give me grace to choose with Mary, that bette part which may never be taken from mee, chiefly to serve and follow thee, that so I may turne this freedome from the bond of mariage only the more to thy service, an may become thy bondwoman to serve and praise thee day and night like Hanna, so long as I live. (I3r, I3v)

In her study of the manuscript history of Richardson's writings, Victoria Burke has convincingly demonstrated Richardson's interest in revising her own prayers, her "revising sensibility" as an author. ${ }^{34}$ But what I find striking about this particular prayer is its explicit invocation of - and expectation of - not a revising author so much as a revising reader. Clearly Richardson expects her daughters and other future readers of her printed Legacie to transform the specific, authorial "I" of the "sorrowfull widowes prayer" into a new "I": that of the pious reader who is experiencing a "like occasion." The biographical details about Richardson's children ("left destitute" but now "well settled for this life") define the speaking "I" in terms of the specifics of Richardson's own life. The hypothetical reader's "I," on the other hand, must sift through and reimagine these details, giving new identities to "my deare husband," to "thy bondwoman," and, ultimately, to "I." The autobiographical context of Richardson's writing informs and shapes her construction of this prayer, but it also bleeds into the future life of her text and its readers, who will resituate Richardson's words to fit their own individual circumstances. This anticipation of and accommodation for her future readership depends upon a cyclical conception of time that makes room for the unique, individual experiences of future readers. Richardson's prayers-unlike the more general spiritual advice found in Leigh's A Mothers Blessing or Jocelin's Mothers Legacie - are set down in precise language for future recitation and reflection, but they are not static or rigid documents. Despite its adherence to set forms, Richardson's advice book is to a great degree an experimental text that offers sites for personal, spiritual adaptation as one of its key legacies to future generations.

The penultimate prayer of Book I of the Legacie demonstrates a similar expectation for textual adaptation. An explanatory note before the prayer's heading tells the reader: "Here is one Prayer more which I joyne to these, because it concerned one of my daughters, to whom this Book belonged, though it was lately penned upon a very strange accident" (C7v). The headnote elaborates further on this historical "accident": the prayer is intended as "A thanksgiving to Almighty God, for his most mercifull preservation of my noble kinswoman the lady Eliz. Feeling, and of my owne daughter, the Lady Eliz. Cornwalleis, from drowning under the Bridge, and was long under water: and one worthy Gentlewoman in the company could not bee recovered. This may serve upon any such fearfull accident" (C8r). As with the "Sorrowfull widdowes prayer," this prayer is meant to be adapted to the specific circumstances of future readers. But what makes this call for revision particularly remarkable is the unusual specificity of the original incident, compared with the relatively common condition of widowhood Richardson provides so much detail about her daughter's accident that it would be difficult to imagine an identical situation occurring in the future; this prayer of thanksgiving virtually requires future readers to adapt the circumstances of this "fearfull accident" to the particular context of their own lives for the prayer to have any meaning at all. Richardson takes personal events and encourages readers to transform them into a template for spiritual reflection; God's mercy in this particular instance will translate into mercy for any future "fearfull accident."

In offering fellow Protestants this type of spiritual model-one that moves from the personal to the general, then back to the personal-Richardson creates both a guide for her children and other believers and a record of her own familial and spiritual history. Much in the same way that annotated Books of Hours could serve as systematic records of "a collective family identity," Richardson's Legacie not only creates structures for Protestant piety in the absence of the Book of Common Prayer but also provides a textual space for the personal histories and legacies that these prayers invoke. ${ }^{35}$ And yet, unlike Books of Hours, in which blank pages and borders were often annotated with notes and family records, this space in the Legacie is not a marginal one. Richardson strikingly asserts the validity of her own experiences and maternal agency within the body of her text, not in marginal annotations. Though the set prayers in the Legacie are adaptable according to cyclical changes in the calendar and the personal history of its reader at any given moment, Richardson's front matter, overall rationale for her text, and inclusion of biographical details ascribe it a fixed historical position that functions quite tangibly to showcase her own construction of a maternal family lineage. It is in this confluence of prayer book and family history that the Legacie succeeds as far more than a substitute for the banned Prayer Book. The formal borrowings and experimentations that comprise Richardson's text ultimately yield a generically flexible space that blurs the distinctions between prayer, family history, and legacy writing. Richardson offers a collection of prayers to her descendants that simultaneously produces a record of her own personal involvement in her family's spiritual future.

The explanatory note's assertion that the prayer of thanksgiving was "lately penned" and added to the text of the Legacie reminds us that Richardson revised and expanded her collection of prayers during her lifetime. But it also makes visible that the textual legacy she leaves to her children is in part based on their own experiences. There is a temporal, diachronic fluidity implied by this document that shapes its family legacy: Richardson revises and adds prayers to the Legacie during her life, then passes along a spiritual template for her daughters that is based in part on one of her own daughter's "fearfull accident[s]." She also notes at the beginning of Book II that many of her original prayers "composed for the instructions of my children, \& grand-children" were modeled "after the example of my dear parents, Sir Thomas Beaumont, and his Lady, Of Stoughton," an acknowledgment that positions the Legacie as an already inherited set of textual 
and spiritual discourses that Richardson can, in turn, transform and pass down to her own children (D2v). By citing the multiple steps in this process of bequeathal and de-emphasizing a strictly linear model of textual dissemination, the Legacie advertises a degree of give-and-take between mother and child and between author and reader that subtly counters seventeenth-century patrilinear modes of generational transmission in England, according to which younger generations substituted for and replaced previous ones, and maternal contributions to inheritance were often ignored or devalued. ${ }^{36}$ In offering her book to her children as a "portion of Grace" to replace the "portions of wealth" that she is unable to provide them, Richardson situates her prayers within a clearly defined system of inheritance. At the same time, she locates herself at the center of a multigenerational process of transmission, thereby reaffirming the value of her own spiritual and biographical experiences (A2v). Instead of relying on a bold assertion of authorial intent or maternal power, Richardson gains authority as a writer and mother through a tacit acknowledgment of the reciprocity between generations and through her ability to remember and record those moments when such give-and-take occurs. Neither completely self-effacing nor radically empowering, Richardson's Legacie insists that the personal and spiritual circumstances of her own life are crucial components of the legacy that she offers to her daughters and necessary foundations for the spiritual template that she offers to a broader community of Protestants.

Though Richardson borrows from a wide range of literary models-including the Bible, Catholic Books of Hours, and the Book of Common Prayer-the Legacie is not merely a textual collage. It is precisely because Richardson's text is not a Bible, is not a Book of Hours, and is not the Prayer Book that it can transform material from these sources into an expansive and supplemental work that is more suitable to the complex range of Richardson's spiritual, familial, and political agendas than any of these genres alone would be. Richardson's creative use of literary and religious structures in the Legacie makes possible a text that cannot only substitute for the banned Prayer Book but can also advertise maternal authority and family history, contribute original poems and prayers to a bourgeoning Protestant print culture, and encourage the individualized development of personal piety. Building upon standard textual forms and the foundational documents of Protestant culture, Richardson creates not only a new form, but a new familial and spiritual community.

I want to conclude by addressing the one genre that I have conspicuously omitted from my arguments about Richardson: the genre of the will. In The Imprint of Gender, Wendy Wall makes the important claim that early modern legacy books were often written by women who were denied the legal right to dispose of material goods through wills. Many women who published mothers' manuals during this period, she argues, deploy the language and form of wills in order to subtly reclaim the inheritance rights that they were culturally denied. Women like Jocelin and Leigh who were married and therefore precluded from writing wills could use the rhetorical posture of the deathbed to authorize their writings, a substitution that explains in part the "flourishing of the legacy form" in early modern England. ${ }^{37}$ Wall's thesis that the rhetoric of will-making was a particularly appealing and useful strategy to those women who wished to publish their advice has greatly influenced subsequent scholarship on women's legacy books, and it offers a reading of the legacy genre that nicely takes into account the economic conditions (and specific economic limitations) under which these texts were produced. But considering Richardson as a case study brings to the forefront some of the limitations of Wall's thesis and implicitly argues for a new critical method of approaching this group of texts.

First, the argument that legacy books functioned as substitutions for women's wills does not directly apply to Richardson, as both her text and the details of her life make clear. Though she is keenly aware of herself as an older woman, Richardson does not use the position of the deathbed to authorize her voice nor does she claim to be nearing death in her text. ${ }^{38}$ And, though the poverty in which she was left after the death of her second husband denies her material goods to pass down to her children, Richardson was a widow and legally able to write a will. ${ }^{39}$ She nevertheless chose to write her Legacie, publish it, and dedicate it to her daughters instead of writing a formal will. This fact alone suggests a motive for this text (and, by extension, this textual form) that lies beyond seventeenth-century limitations on women's legal rights.

Second and most suggestive, though Richardson's personal situation was quite different from that of writers such as Leigh and Jocelin, the Legacie can still offer us another way of reading and understanding the textual, spiritual, and cultural significance of legacy books as a genre. I have argued here for the generic fluidity and creativity of the Legacie; a more complex understanding of the formal structure of this text and others like it will allow us to rethink the generic possibilities of the mother's manual and to read anew the potential for selfauthorization that this form allows. Seeing legacy books as substitutes for wills, or the Legacie as a substitute for the Book of Common Prayer, gives us only part of the picture: the rhetoric of will-making is only one of the many generic models that help to shape these legacy books, and future scholarship will no doubt bring to light many other intertextual connections and structural models in addition to the ones I've discussed here. I suggest that the appeal of the legacy book as a genre to early modern women writers may be directly related to the ability of these texts to exceed and supplement the generic potential of any one of the many forms that comprise them. The extraordinary hybridity of early modern legacy books may ultimately tell us more about the cultural significance of these texts than do their individual structural components. Though they may have served as substitutes for legal impossibilities or banned religious texts, these books also bring into visibility forms of maternal agency that are largely invisible in the legal language of seventeenth-century wills or in the proscribed litany of the Book of Common Prayer. These texts thus make it possible to articulate the role of mothers in the 
generational transmission of educational principles, spiritual guidelines, and templates for private piety. For Richardson at least, the legacy book enables a localized discourse of maternal authority and Protestant ideology that is not limited to its moment of historical materialization but can inspire other lived patterns of piety as it is rehearsed, revisited, and reimagined in the future.

\section{Notes}

I wish to thank Julie A. Eckerle and the members of the North Carolina Research Group on Medieval and Early Modern Women for their suggestions and thoughtful comments on earlier drafts of this essay.

1 Valerie Wayne, "Advice for Women from Mothers and Patriarchs," Women and Literature in Britain 1500-1700, ed. Helen Wilcox (Cambridge: Cambridge UP, 1996) pp. 56-79, esp. p. 62.

2 See Kristen Poole, "The fittest closet for all goodness': Authorial Strategies of Jacobean Mothers' Manuals," SEL 35.1 (1995): 69-88, esp. p. 69, n. 1.

3 Important critical studies include Sylvia Brown, ed. Women's Writing in Stuart England: The Mothers' Legacies of Dorothy Leigh, Elizabeth Joscelin and Elizabeth Richardson (Phoenix Mill, England: Sutton, 1999); Betty S. Travitsky, "The New Mother of the English Renaissance: Her Writings on Motherhood," The Lost Tradition. Mothers and Daughters in Literature, ed. Cathy N. Davidson and E.M. Broner (New York: Frederick Ungar, 1980), pp. 33-43; Elaine V. Beilin, Redeeming Eve: Women Writers of the English Renaissance (Princeton: Princeton UP, 1987), esp. pp. 247-85; Martha J. Craig, "Write it upon the walls of your houses': Dorothy Leigh's The Mothers Blessing," Women's Life-Writing: Finding Voice/Building Community (Bowling Green, OH: Bowling Green State UP, 1997), pp. 191-208; Teresa Feroli, "Infelix Simulacrum': The Rewriting of Loss in Elizabeth Jocelin's The Mothers Legacie," ELH 61.1 (1994): 89-102; Wendy Wall, The lmprint of Gender: Authorship and Publication in the English Renaissance (Ithaca: Cornell UP, 1993), esp. pp. 283-96; Wayne; and Poole.

4 See S. Brown, pp. 144-49.

5 Ibid., p. 143.

6 Victoria E. Burke, "Elizabeth Ashburnham Richardson's 'motherlie endeauors' in Manuscript," English Manuscript Studies 1100-1700: Writings by Early Modern Women, vol. 9, ed. Peter Beal and Margaret J.M. Ezell (London: The British Library, 2000), pp. 98-113, esp. p. 111. Burke offers a thorough analysis of both manuscripts, MS V.1.511 in the Folger Shakespeare Library, Washington DC and ASH 3501 in the East Sussex Record Office at Lewes (Ashburnham Papers)

7 See S. Brown, pp. 142-3 and Burke, pp. 105-11.

8 See Margaret J.M. Ezell, The Patriarch's Wife: Literary Evidence and the History of the Family (Chapel Hill: $U$ of North Carolina P, 1987), pp. 62-100 in addition to the essays in Beal and Ezell, English Manuscript Studies.
9 Elizabeth Richardson, A Ladies Legacie to her Daughters (London, 1645). Unless otherwise noted, all citations will be from this edition and will be cited parenthetically in the text.

10 See S. Brown, pp. 142-50 for biographical information on Richardson. For Buckingham's association with Catholicism, see Frances E. Dolan, Whores of Babylon: Catholicism, Gender, and Seventeenth-Century Print Culture (Ithaca: Cornell UP, 1999), pp. 95-6 and David Underdown, A Freeborn People: Politics and the Nation in Seventeenth-Century England (Oxford: Clarendon, 1996), pp. 33-44.

11 S. Brown, p. 149

12 Roger S. Wieck, "The Book of Hours," The Liturgy of the Medieval Church, ed. Thomas J. Heffernan and E. Ann Matter (Kalamazoo: Medieval Institute, 2001), pp. 473-513, esp. p. 473.

13 Ibid., p. 478.

14 Kathleen Ashley, "Creating Family Identity in Books of Hours," Journal of Medieval and Early Modern Studies 32.1 (2002): 145-65, esp. p. 148 and p. 150.

15 S. Brown, p. 253, n. 131.

16 For a detailed discussion of the Sternhold and Hopkins psalter, see Hannibal Hamlin, Psalm Culture and Early Modern English Literature (Cambridge: Cambridge UP, 2004), esp. pp. 19-50. For the importance of the psalms to the English Reformation, see Beilin, pp. 144-50.

17 See Ian Green, Print and Protestantism in Early Modern England (Oxford: Oxford UP, 2000) and Tessa Watt, Cheap Print and Popular Piety, 1550-1640 (Cambridge: Cambridge UP, 1991).

18 S. Brown, pp. 149-50.

19 The imprint phrase "to be sold at his house" strengthens the claim that Harper was the publisher-not simply the printer-of the Legacie. My thanks to Alan B. Farmer and Zachary Lesser for their assistance on matters concerning the early modern book trade.

20 H.R. Plomer, Dictionary of Booksellers and Printers: 1641-1667 (London: Bibliographical Society, 1907).

21 Zachary Lesser, Renaissance Drama and the Politics of Publication: Readings in the English Book Trade (Cambridge: Cambridge UP, 2004), esp. p. 95.

22 John E. Booty, "Communion and Commonweal: The Book of Common Prayer," The Godly Kingdom of Tudor England: Great Books of the English Reformation, ed. Booty (Wilton, CT: Morehouse-Barlow, 1981), pp. 139-216, esp. p. 177.

23 Booty, "Communion and Commonweal," p. 177. In Common Prayer: The Language of Public Devotion in Early Modern England (Chicago: U of Chicago P, 2001), Ramie Targoff argues that "behind the introduction of a liturgy emphasizing the worshippers' active participation and consent lies the establishment's overarching desire to shape personal faith through public and standardized forms" (18). See also Targoff's discussion of Puritan opposition to the Prayer Book, pp. 36-56.

24 The Book of Common Prayer (1559), ed. Booty (Charlottesville, VA: U of Virginia P for the Folger Shakespeare Library, 1976), esp. p. 16. All citations will be taken from this edition of the Book of Common Prayer and will be cited parenthetically in the text.

25 It should be noted that the Book of Common Prayer was itself in many ways a hybrid text, based largely upon the structure of medieval liturgical texts but reforming these liturgies for the use and direction of Protestant worshippers. See Booty, Book of Common Prayer, pp. 366-68. 
26 See S. Brown, p. 249, n. 21 and p. 150 for Richardson's particular affinity for this section of the Book of Common Prayer.

27 See also S. Brown, p. 251, n. 80.

28 Booty, "Communion and Commonweal," pp. 172-73.

29 Alison A. Chapman, "Now and Then: Sequencing the Sacred in Two Protestan Calendars," Joumal of Medieval and Early Modem Studies 33.1 (2003): 91-123, esp. p. 102.

30 Here again, the publication history of Richardson's text is significant. In 1649, four years after publishing the Legacie, Thomas Harper printed and published An Annuall Almanacke: Shewing, how to read the Chapters of the whole Bible, from the beginning of Genesis, to the end of the Revelation, once in the Yeare, by so many Chapters every day by Walter Holmes. The similarities between the structure of this Protestant almanac and the Legacie's own format of set prayers - both fitting substitutes for the banned Book of Common Prayer - offer scintillating, if speculative, evidence that political and religious motives may have driven Richardson to publish the Legacie in 1645, with Harper as its publisher.

31 See Chapman, pp. 114-17 and Targoff, pp. 14-35.

32 See S. Brown, p. 144

33 See also the prayer in Book I designated as "A private morning Prayer" (B2r).

34 Burke, p. 111.

35 Ashley, p. 148

36 The scholarship on early modern inheritance patterns is sizeable and impossible to cite fully here. Important studies include Amy Louise Erickson, Women and Property in Early Modern England (New York: Routledge, 1993); Family and Inheritance: Rural Society in Western Europe 1200-1800, ed. Jack Goody, Joan Thirsk, and E.P. Palmer (Cambridge: Cambridge UP, 1976); Eileen Spring, Law, Land \& Inheritance: Aristocratic Inheritance in England, 1300-1800 (Chapel Hill: U of North Carolina P, 1993); and Lisa Jardine, Still Harping on Daughters; Women and Drama in the Age of Shakespeare (New York: Columbia UP, 1983), esp. pp. 68-102.

37 Wall, Imprint of Gender, p. 295.

38 For Richardson's self-consciousness about her age, see S. Brown, p. 150. Burke notes that Richardson's text was different from that of most other mothers' legacies because "it was not published after her death ... [but] in 1645 when she was still very much alive" (99). Richardson, in other words, did not use a narrative of impending death to authorize her publication of the Legacie.

39 For the details of Richardson's marriages and subsequent poverty, see S. Brown, pp. $144-8$.

\section{Chapter 9}

\section{Intersubjectivity, Intertextuality, and Form in the Self-Writings of Margaret Cavendish}

\author{
Elspeth Graham
}

Margaret Cavendish was a prolific and innovative writer. She produced texts in a large number of genres, and the concerns of her texts range widely, often crossing our modern demarcations of subject discipline. The variety, range, and fluidity of her writings have made her work a particularly rich critical object in the last twenty years or so. This is in part due to the unusual nature of her writing; Cavendish herself refers to her writing as "scribbling," alludes to the way her "words run stumbling out of [her] mouth," and, in naming an early book The World's Olio, implies that the composition of her texts is like a musical medley, or a thick stew, full of disparate ingredients, cooked together. ${ }^{1}$ If we take this description seriously, rather than as an instance of conventional feminine modesty or routine selfdeprecation, it suggests another aspect of the richness of her writing as a critical object. In its spontaneity, and with its lack of strict adherence to the stabilities of aesthetic tradition, her work has a curiously open quality: it is available for a plurality of readings because it is actually quite unworked. ${ }^{2}$

Because of the complexity and diversity of her texts (as well as the sheer number of them), critical writing on Cavendish has typically tended to isolate particular genres or themes within her oeuvre as a focus. My own essay here approaches her writing rather differently. It starts with the observation that Cavendish is, above all, a deeply autobiographical writer and that an autobiographical imperative cuts across her use of different forms and her explorations of different themes and subject matters. The prime questions the essay addresses are how and why Cavendish, in an age when there is no established autobiographical tradition for her to work within, or to respond to, uses autobiographical modes so extensively. Rather than separating out her most directly autobiographical texts (A true Relation of my Birth, Breeding, and Life and the biography of her husband, her Life of William Cavendish, which is also in many ways, I shall suggest, a further version of her own story) and concentrating 